\title{
Influence of patient age and oral contraceptives on different variables in breast cancer
}

\author{
Influenţa vârstei pacientelor şi a contraceptivelor orale asupra \\ diferitelor variabile în cancerul de sân
}

\author{
Alfred Redalf Alen Gheorghiu \\ Catedra de Chirurgie, Facultatea de Medicină, Universitatea Transilvania, Braşov, România Spitalul \\ Clinic Judeţean de Urgenţă, Braşov, România
}

\begin{abstract}
Introduction. Breast cancer continues to be a major challenge, both in terms of risk factors and how they influence its evolution, as well as in terms of its treatment.

Objectives. This study will show how age and oral contraceptives, used at different stages of patients' lives, influence or not, the evolution of breast cancer.

Materials and method. The study was performed on a group of 90 breast cancer patients, hospitalized and operated in the Surgery Clinic 2 of the Braşov County Emergency Clinical Hospital.

Results and discussions. The results of this study show how age and oral contraceptives influence the various variables of breast cancer, thus contributing to the understanding of the development of different forms of breast cancer and the application of therapeutic methods as effective as possible.

Conclusions. Age and oral contraceptives significantly influence the development of breast cancer, depending on their use, at different stages of patients' lives.
\end{abstract}

Keywords: age, oral contraceptives, breast cancer

\section{REZUMAT}

Introducere. Cancerul mamar reprezintă în continuare o mare provocare, atât în ceea ce priveşte factorii de risc şi modul în care aceştia influenţează evoluţia lui, cât şi în ceea ce priveşte tratamentul acestuia.

Obiective. Acest studiu va arăta cum vârsta şi contraceptivele orale, utilizate în diferite etape ale vieţii pacientelor, influnţează sau nu modul de evoluţie a cancerului de sân.

Materiale şi metodă. Studiul a fost efectuat pe un lot de 90 de paciente cu cancer de sân internate şi operate în Clinica Chirurgie 2 a Spitalului Clinic Judeţean de Urgenţă Braşov.

Rezultate şi discuții. Rezultatele acestui studiu arată cum vârsta şi contraceptivele orale influenţează diferitele variabile ale cancerului de sân, contribuind astfel la înţelegerea dezvoltării diferitelor forme de cancer de sân şi la aplicarea unor metode terapeutice cât mai eficiente.

Concluzii. Vârsta şi contraceptivele orale influenţează în mod semnificativ dezvoltarea cancerului de sân în funcţie de utilizarea lor în diferitele etape ale vieţii pacientelor.

Cuvinte cheie: vârstă, contraceptive orale, cancer de sân

\section{INTRODUCERE}

Cancerul de sân, în contextul actual, reprezintă forma cea mai frecventă de cancer la femei, cu o mortalitate crescută. Estimările recente ale IARC spun despre cancerul de sân că este cel mai frecvent tip diagnosticat de cancer la femei, reprezentând $24,2 \%$ dintre toate cazurile noi de neoplasm în rândul femeilor. Rata de incidenţă depăşeşte cu mult rata altor tipuri de cancer, atât în ţările dezvoltate, cât şi în cele în curs de dezvoltare. După cum am spus, este şi principala cauză de deces la femei, reprezentand $15 \%$ din totalul deceselor cauzate de cancer la acestea. În România, în 2018, cancerul de sân ocupa prima poziţie, cu 9.629 cazuri noi, adică 25,1\%, faţă de cancerul de colon (4.576 cazuri noi, adică $11,9 \%)$ şi cancerul de col uterin (3.308 cazuri noi, adică 8,6\%) (1). În UE, sunt diagnosticate anu- 
al peste 400.000 de cazuri noi (2). Legat de numărul de decese prin cancer de sân înregistrat în rândul femeilor în România, acesta a fost în 2017 de 3.484, în creştere faţă de 2016, când s-au înregistrat 3.457 decese (3).

În România, 80\% dintre cancerele de sân sunt diagnosticate în fază avansată, situaţie în care se poate asigura doar prelungirea supravieţuirii pacientelor, fără a se putea face vindecarea lor. Doar în maximum $20 \%$ dintre cazurile de cancer de sân (cancer de sân precoce), tratamentul poate obţine vindecarea (3).

S-a observat că riscul de dezvoltare a cancerului de sân creşte cu vârsta, astfel că, între 30 şi 40 de ani, 1 din 250 femei va dezvolta cancer de sân, iar între 40 şi 50 de ani, 1 din 70 femei va dezvolta cancer de sân (4)

După cum am arătat deja, cancerul de sân se caracterizează printr-o morbiditate şi o mortalitate crescute, acest lucru fiind influenţat şi de prezenţa unor factori de risc hormonali (5-7).

O importanţă deosebită în dezvoltarea cancerului de sân trebuie acordată şi factorilor hormonali de risc, care pot influența în diferite moduri evoluţia acestuia (8). Factorii hormonali de risc în cancerul de sân pot influenţa şi conduita terapeutică de urmat $(9,10)$.

Factorii hormonali ce influenţează apariţia şi evoluţia cancerului de sân sunt: vârsta, ciclul menstrual şi menopauza, alăptarea, obezitatea, contraceptivele orale (11-13).

Acest studiu şi-a propus să arate cum o parte dintre aceşti factori influenţează diferitele variabile din cancerul de sân $(14,15)$, urmărind să evidenţieze în ce fel vârsta, menarha, menopauza şi contraceptivele orale influenţează apariţia diferitelor forme de cancer de sân.

Variabilele cu care interacţionează aceşti factori sunt reprezentate de: fenotipul tumorii, dimensiunea tumorii, fenotipul tumorii şi starea HER2 a acestuia, tipul histopatologic şi grading-ul (gradul de diferenţiere) tumoral $(5,16,17)$.

\section{MATERIALE ŞI METODĂ}

Acest studiu s-a bazat pe analiza unui lot de 90 de paciente cu tumori maligne de sân, în diferite stadii, internate şi operate în perioada 2009-2014 în Secţia Chirurgie 2 a Spitalului Clinic Judeţean de Urgenţă Braşov. Studiul a folosit datele din foile de observaţie ale pacientelor, precum şi un interviu cu fiecare pacientă din lotul studiat, care a avut ca scop completarea unui chestionar legat în special de vârstă, menarhă, menopauză, sarcină şi utilizarea de contraceptive orale. Alături de acest chestionar, s-a folosit şi studiul IHC (imuno-histo-chimic), efectuat pe examenul histopatologic al piesei tumorale excizate intraoperator. Examenul IHC a arătat prezenţa sau absenţa receptorilor estrogenici sau progesteronici la nivelul celulelor tumorale, precum şi starea HER2 a ţesutului tumoral examinat. Tot în urma examenului histopatiologic, s-a putut preciza şi tipul histopatologic de cancer de sân, precum şi grading-ul (gradul de diferenţiere) tumoral.

Analiza statistică a rezultatelor obţinute s-a făcut folosind testul Chi pătrat şi tabelele de contingenţă, precum şi regresia logistică binară.

\section{REZULTATE}

Rezultatele studiului au fost obţinute în urma aplicării chestionarului mai sus menţionat şi a datelor culese din foile de observaţie ale pacientelor.

Legat de vârsta de apariţie a cancerului de sân la cele 90 de paciente din lotul studiat:

- $71 \%$ dintre cazuri s-au încadrat în intervalul de vârstă de 55-70 de ani;

- 29\% dintre cazuri s-au încadrat în intervalul de vârstă de 35-54 de ani (vezi tabel 1, fig. 1)

TABEL 1. Repartiția pe vârstă a pacientelor

\begin{tabular}{|l|c|c|}
\hline Nr. cazuri & $\begin{array}{c}\text { Interval vârstă } \\
35-54 \text { ani }\end{array}$ & $\begin{array}{c}\text { Interval vârstă } \\
55-75 \text { ani }\end{array}$ \\
\hline 90 de cazuri & 26 cazuri $(29 \%)$ & 64 cazuri $(71 \%)$ \\
\hline
\end{tabular}

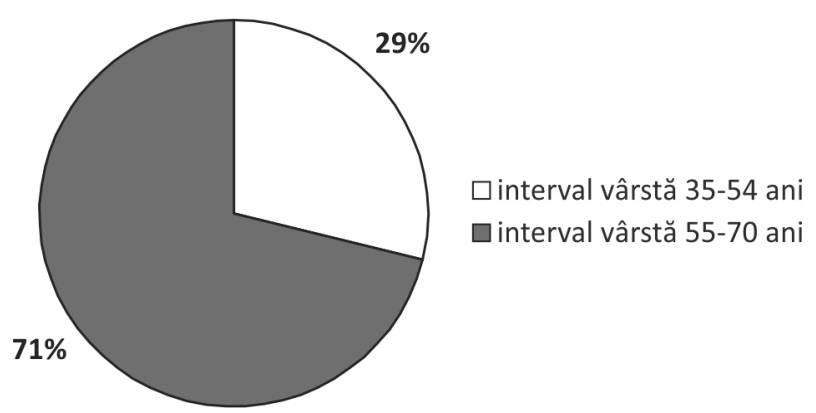

FIGURA 1. Repartiția pe vârstă a pacientelor

Apariţia ciclului menstrual la cele 90 de paciente din lotul studiat a avut următoarea repartizare:

- $29 \%$ dintre cazuri au avut ciclul menstrual la 10-11 ani;

- $32 \%$ dintre cazuri au avut ciclul menstrual la 12 ani;

- 39\% dintre cazuri au avut ciclul menstrual după vârsta de 12 ani. (vezi tabel 2, fig. 2) 
TABEL 2. Repartitia pacientelor din lotul studiat în funcție de vârsta de instalare a ciclului menstrual

\begin{tabular}{|l|l|l|l|}
\hline $\begin{array}{l}\text { Nr. total } \\
\text { cazuri }\end{array}$ & $\begin{array}{l}\text { Ciclul menstrual } \\
\text { instalat la } \\
10-11 \text { ani }\end{array}$ & $\begin{array}{l}\text { Ciclul menstrual } \\
\text { instalat la } 12 \text { ani }\end{array}$ & $\begin{array}{l}\text { Ciclul menstrual } \\
\text { instalat după } \\
12 \text { ani }\end{array}$ \\
\hline $\begin{array}{l}90 \text { de } \\
\text { cazuri }\end{array}$ & 26 cazuri $(29 \%)$ & 29 cazuri (32\%) & 35 cazuri (39\%) \\
\hline
\end{tabular}

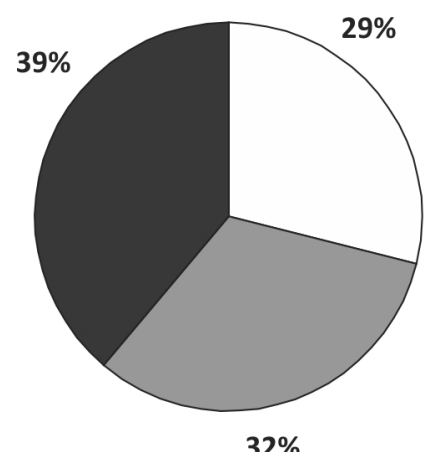

$32 \%$ $\square$ ciclul menstrual instalat la 10-11 ani

$\square$ ciclul menstrual instalat la 12 ani

- ciclul menstrual instalat după 12 ani

FIGURA 2. Repartitia pacientelor din lotul studiat în funcție de vârsta de instalare a ciclului menstrual

Dacă analizăm instalarea menopauzei la cele 90 de cazuri studiate, observăm că:

- în 36\% dintre cazuri, menopauza s-a instalat înainte de vârsta de 55 ani

- în 64\% dintre cazuri, menopauza s-a instalat după vârsta de 55 de ani (vezi tabel 3, fig. 3).

TABEL 3. Repartiția pacientelor din lotul studiat în funcție de vârsta de instalare a menopauzei

\begin{tabular}{|l|l|l|}
\hline $\begin{array}{l}\text { Număr cazuri } \\
\text { studiate }\end{array}$ & $\begin{array}{l}\text { Menopauza instalată } \\
\text { înainte de } 55 \text { de ani }\end{array}$ & $\begin{array}{l}\text { Menopauza instalată } \\
\text { după } 55 \text { de ani }\end{array}$ \\
\hline $\begin{array}{l}90 \text { cazuri din } \\
\text { care }\end{array}$ & 32 cazuri $(36 \%)$ & 58 cazuri $(64 \%)$ \\
\hline
\end{tabular}

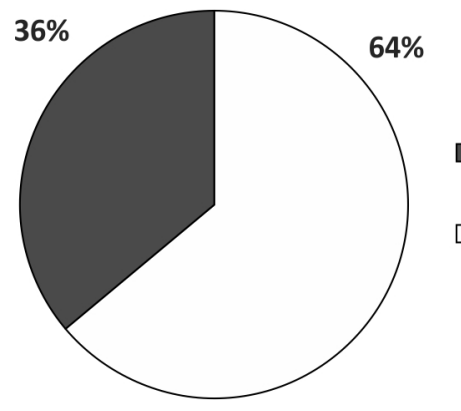

- menopauza instalată înainte de 50 de ani

$\square$ menopauza instalată după de 50 de ani

FIGURA 3. Repartiția pacientelor din lotul studiat în funcție de vârsta de instalare a menopauzei

Folosirea contraceptivelor orale de către cele 90 de paciente din lotul studiat a fost astfel repartizată:

- 33\% dintre cazuri au utilizat contraceptive orale înainte de prima sarcină;

- $31 \%$ dintre cazuri au utilizat contraceptive orale după prima sarcină, pe o perioadă mai mare de 10 ani;

- $36 \%$ dintre cazuri au utilizat contraceptive orale după menopauză, pentru diferite alte afecţiuni (vezi tabel 4, fig. 4).

TABEL 4. Rezultatele utilizării contraceptivelor orale pe lotul studiat

\begin{tabular}{|l|l|l|l|}
\hline $\begin{array}{l}\text { Nr. cazuri } \\
\text { studiate }\end{array}$ & $\begin{array}{l}\text { Utilizare } \\
\text { contraceptive } \\
\text { orale înainte de } \\
\text { prima sarcină }\end{array}$ & $\begin{array}{l}\text { Utilizare } \\
\text { contraceptive orale } \\
\text { după prima sarcină, } \\
\text { mai mult de 10 ani }\end{array}$ & $\begin{array}{l}\text { Utilizare } \\
\text { contraceptive } \\
\text { orale după } \\
\text { menopauză }\end{array}$ \\
\hline $\begin{array}{l}90 \text { de } \\
\text { cazuri }\end{array}$ & $\begin{array}{l}30 \text { cazuri } \\
(33 \%)\end{array}$ & $\begin{array}{l}28 \text { cazuri } \\
(31 \%)\end{array}$ & $\begin{array}{l}32 \text { cazuri } \\
(36 \%)\end{array}$ \\
\hline
\end{tabular}

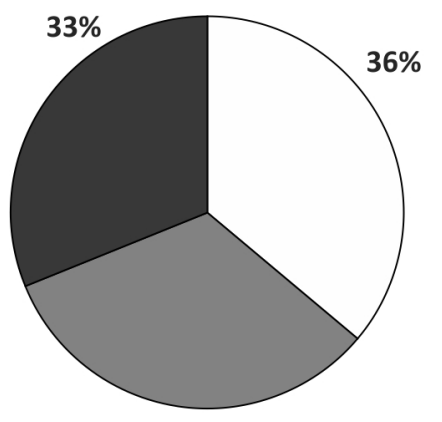

$31 \%$

FIGURA 4. Rezultatele utilizării contraceptivelor orale pe lotul studiat

\section{Rezultate statistice obținute folosind Testul Chi pătrat şi tabelele de contingență}

Pe baza rezultatelor obţinute mai sus, s-a trecut la analiza statistică a acestora, folosind testul Chi pătrat şi tabelele de contingenţă; a fost considerat coeficient de semnificaţie statistică $\mathrm{p}<0,01-0,05$. S-a analizat legătura dintre vârsta pacientelor şi utilizarea contraceptivelor orale, cu diverse variabile ale cancerului de sân, pe lotul de paciente studiat.

TABEL 5. Legătura dintre utilizarea contraceptivelor orale înainte de prima sarcină şi fenotipul cancerului, dimensiunea tumorii de sân, fenotipul asociat cu starea HER2 a tumorii, tipul histologic de cancer şi cu grading-ul tumoral

\begin{tabular}{|c|c|c|c|}
\hline $\begin{array}{l}\text { Utilizare contraceptive } \\
\text { înainte de prima } \\
\text { sarcină / variabile }\end{array}$ & $\begin{array}{l}\text { Nivel de } \\
\text { semnificație (p) }\end{array}$ & $\mathrm{Nu}(\%)^{\mathrm{a}}$ & Da $(\%)^{b}$ \\
\hline $\begin{array}{l}\text { Fenotipul tumorii } \\
\text { ER+/PR+ } \\
\text { ER-/PR- } \\
\text { ER-/PR+ } \\
\text { ER+/PR- }\end{array}$ & $\begin{array}{l}0,000 * * * \\
0,000 * * * \\
0,343\left(\mathrm{NS}^{\mathrm{c}}\right) \\
0,048 * *\end{array}$ & $\begin{array}{c}79,7 \\
11,9 \\
8,5 \\
0,0\end{array}$ & $\begin{array}{l}\mathbf{3 5 , 5} \\
\mathbf{5 4 , 8} \\
3,2 \\
6,5\end{array}$ \\
\hline $\begin{array}{l}\text { Dimensiunea tumorii } \\
<2 \mathrm{~cm} \\
2-4 \mathrm{~cm} \\
>5 \mathrm{~cm}\end{array}$ & $\begin{array}{l}0,000^{* * *} \\
0,000^{* * *} \\
0,849 \\
\end{array}$ & $\begin{array}{c}11,9 \\
79,7 \\
8,5 \\
\end{array}$ & $\begin{array}{c}54,8 \\
35,5 \\
9,7 \\
\end{array}$ \\
\hline $\begin{array}{l}\text { Fenotipul tumorii şi } \\
\text { starea HER2 } \\
\text { ER+/PR+HER2+ } \\
\text { ER-/PR-HER2+ } \\
\text { ER+/PR+HER2- } \\
\text { ER-/PR-HER2- } \\
\text { ER+/PR-HER2- } \\
\text { ER-/PR+HER2- }\end{array}$ & $\begin{array}{l}0,041 * * \\
0,000 * * * \\
0,026 * * \\
0,183 \text { (NS) } \\
0,048 * * \\
0,343 \text { (NS) } \\
\end{array}$ & $\begin{array}{c}40,7 \\
0,0 \\
39,0 \\
11,9 \\
0,0 \\
8,5\end{array}$ & $\begin{array}{l}19,4 \\
32,3 \\
16,1 \\
22,6 \\
6,5 \\
3,2\end{array}$ \\
\hline $\begin{array}{l}\text { Tipul histopatologic de } \\
\text { cancer } \\
\text { Carcinom ductal } \\
\text { Carcinom lobular } \\
\text { Alte tipuri histologice }\end{array}$ & $\begin{array}{l}0,012 * * \\
0,164 \text { (NS) } \\
0,733 \text { (NS) }\end{array}$ & $\begin{array}{c}15,3 \\
16,9 \\
8,5\end{array}$ & $\begin{array}{c}\mathbf{3 8 , 7} \\
6,5 \\
6,5\end{array}$ \\
\hline
\end{tabular}




\begin{tabular}{|l|l|c|c|}
\hline $\begin{array}{l}\text { Utilizare contraceptive } \\
\text { înainte de prima } \\
\text { sarcină / variabile }\end{array}$ & $\begin{array}{l}\text { Nivel de } \\
\text { semnificație (p) }\end{array}$ & $\mathrm{Nu} \mathrm{( \% )^{ \textrm {a } }}$ & $\mathrm{Da}(\%)^{\mathrm{b}}$ \\
\hline Grading tumoral & $0,000^{* * *}$ & 5,1 & $\mathbf{3 8 , 7}$ \\
G1 & $0,007^{* *}$ & 20,3 & 0,0 \\
G2 & 0,763 (NS) & 15,3 & 12,9 \\
\hline
\end{tabular}

În urma analizei statistice, s-a observat că pacientele care au folosit contraceptive orale înainte de prima sarcină au forme de cancer de sân preponderent din fenotipul ER-/PR-la 54,8\% dintre cazuri, urmate de fenotipul ER+/PR+, la 35,5\% dintre cazuri. Acest lucru arată că utilizarea contreceptivelor orale înainte de prima sarcină nu are o influenţă importantă în dezvoltarea cancerelor de sân, întrucât o mare parte dintre cazuri au avut fenotipul ER-/PR-, ceea ce înseamnă că aceste celule canceroase nu au pe suprafaţa lor receptori pentru estrogen şi progesteron, adică dezvoltarea cancerului la aceste paciente nu este influenţată de hormoni.

Dacă raportăm şi la starea HER2 a acestor cancere, utilizarea de contraceptive orale înainte de prima sarcină, vom observa că predomină fenotipul ER-/PR-, cu HER2+ (32,3\%). Acest lucru arată că utilizarea contraceptivelor orale înainte de prima sarcină poate duce la apariţia de cancere cu agresivitate mai mare și responsivitate dificilă la diferitele terapii utilizate, cu probabilitate mai mare de recidivă.
De asemenea, analiza statistică a scos la iveală un alt aspect al utilizării contraceptivelor orale înainte de prima sarcină, şi anume faptul că marea majoritate a cancerelor de sân apărute la aceste paciente este încadrată în stadiile I şi II de cancer, în proporţie de $90,3 \%$ din totalul cazurilor studiate (evidenţiat în tabel prin dimensiunea tumorii), predominând în această situaţie tipul histologic de carcinom ductal, cu un grading tumoral G1, în proporţie de $38,7 \%$ din totalul cazurilor.

Analiza efectuată ne arată că utilizarea contraceptivelor orale după prima sarcină, pe o perioadă mai mare de 10 ani, duce la apariţia cancerelor de sân, cu fenotipul ER+/PR+, în proprţie de $74,1 \%$, spre deosebire de fenotipul ER-/PR-, în proporţie de $25,9 \%$ din totalul cazurilor studiate. Acest lucru sugerează că folosirea contraceptivelor în această situaţie influenţează apariţia cancerului de sân în măsură mai mare, comparativ cu utilizarea contraceptivelor înainte de prima sarcină. Şi starea HER2+ este prezentă pe fenotipurile de cancer $\mathrm{ER}+/ \mathrm{PR}+$ în proporţie mai mare, ceea ce arată că agresivitatea tumorilor în acest caz este şi ea mare, urmată de o responsivitate scăzută la tratament şi de un risc de recidivă mai mare.

În ceea ce priveşte dimensiunea tumorilor, în această situaţie, vorbim de tumori care nu depăşesc $4 \mathrm{~cm}$ dimensiuni, adică tumori în stadiile I şi II, dar

TABEL 6. Legătura dintre utilizarea contraceptivelor orale după prima sarcină mai mult de 10 ani şi fenotipul de cancer, dimensiunea tumorii de sân în momentul depistării, fenotipul asociat cu starea HER2 a tumorii, tipul histopatologic de cancer de sân şi grading-ul tumoral

\begin{tabular}{|l|c|c|c|}
\hline Utilizare contraceptive după prima sarcină mai & $\begin{array}{c}\text { Nivel de } \\
\text { mult de } 10 \text { ani / variabile }\end{array}$ & Nu (\%) & Da (\%) \\
\hline Fenotipul tumorii & $0,212\left(\mathrm{NS}^{\mathrm{b}}\right)$ & 60,3 & $\mathbf{7 4 , 1}$ \\
ER+/PR+ & 0,917 (NS) & 27,0 & $\mathbf{2 5 , 9}$ \\
ER-/PR- & $0,097^{*}$ & 9,5 & 0,0 \\
ER-/PR+ & 0,349 (NS) & 3,2 & 0,0 \\
ER+/PR- & & & \\
\hline Dimensiunea tumorii & 0,917 (NS) & 27,0 & 25,9 \\
$<2$ cm & 0,212 (NS) & 60,3 & $\mathbf{7 4 , 1}$ \\
$2-4$ cm & $0,052^{*}$ & 12,7 & 0,0 \\
>5 cm & & & \\
\hline Fenotipul tumorii şi starea HER2 & $0,001^{* * *}$ & 22,2 & $\mathbf{5 9 , 3}$ \\
ER+/PR+HER2+ & $0,028^{* *}$ & 15,9 & 0,0 \\
ER-/PR-HER2+ & $0,029^{* *}$ & 38,1 & 14,8 \\
ER+/PR+HER2- & $0,076^{*}$ & 11,1 & $\mathbf{2 5 , 9}$ \\
ER-/PR-HER2- & 0,349 (NS) & 3,2 & 0,0 \\
ER+/PR-HER2- & $0,097^{*}$ & 9,5 & 0,0 \\
ER-/PR+HER2- & & & \\
\hline Tipul histopatologic de cancer & 0,355 (NS) & 20,6 & $\mathbf{2 9 , 6}$ \\
Carcinom ductal & 0,787 (NS) & 12,7 & 14,8 \\
Carcinom lobular & 0,103 (NS) & 4,8 & 14,8 \\
Alte tipuri histologice & & & \\
\hline Grading tumoral & 0,355 (NS) & 19,0 & 11,1 \\
G1 & $0,003^{* * *}$ & 6,3 & $\mathbf{2 9 , 6}$ \\
G2 & 0,472 (NS) & 12,7 & 18,5 \\
G3 & & & \\
\hline
\end{tabular}


predomină stadiul II, în proporţie de $74,1 \%$ dintre cazurile studiate, spre deosebire de stadiul I, în proporţie de $25,9 \%$ dintre cazurile studiate.

Legat de tipul histopatologic al tumorilor, a predominat carcinomul ductal, dar cu grading tumoral G2 frecvent, spre deosebire de utilizarea contraceptivelor orale înainte de prima sarcină, unde a predominat grading-ul tumoral G1.

TABEL 7. Legătura dintre utilizarea contraceptivelor orale după menopauză, pentru alte afecțiuni, şi fenotipul de cancer, dimensiunea tumorii de sân în momentul depistării, fenotipul asociat cu starea HER2 a tumorii, tipul histopatologic de cancer de sân şi grading-ul tumoral

\begin{tabular}{|l|l|c|c|}
\hline $\begin{array}{l}\text { Utilizare contraceptive } \\
\text { după menopauză / } \\
\text { variabile }\end{array}$ & $\begin{array}{l}\text { Nivel de } \\
\text { semnificație (p) }\end{array}$ & Nu (\%) & Da (\%) \\
\hline Fenotipul tumorii & & & \\
ER+/PR+ & $0,003^{\text {b** }}$ & 53,4 & $\mathbf{8 4 , 4}$ \\
ER-/PR- & $0,000^{* * *}$ & 41,4 & 0,0 \\
ER-/PR+ & $0,011^{* *}$ & 1,7 & $\mathbf{1 5 , 6}$ \\
ER+/PR- & 0,288 (NS) & 3,4 & 0,0 \\
\hline Dimensiunea tumorii & & & \\
$<2$ cm & $0,000^{* * *}$ & 41,4 & 0,0 \\
2-4 cm & $0,003^{* * *}$ & 53,4 & $\mathbf{8 4 , 4}$ \\
$>5$ cm & $0,095^{*}$ & 5,2 & 15,6 \\
\hline Fenotipul tumorii si & & & \\
starea HER2 & & & \\
ER+/PR+HER2+ & 0,213 (NS) & 37,9 & $\mathbf{2 5 , 0}$ \\
ER-/PR-HER2+ & $0,013^{* *}$ & 17,2 & 0,0 \\
ER+/PR+HER2- & $0,000^{* * *}$ & 15,5 & $\mathbf{5 9 , 4}$ \\
ER-/PR-HER2- & $0,002^{* * *}$ & 24,1 & 0,0 \\
ER+/PR-HER2- & 0,288 (NS) & 3,4 & 0,0 \\
ER-/PR+HER2- & $0,011^{* *}$ & 1,7 & $\mathbf{1 5 , 6}$ \\
\hline Tipul histopatologic de & & & \\
cancer & & & \\
Carcinom ductal & $0,001^{* * *}$ & 34,5 & 3,1 \\
Carcinom lobular & 0,262 (NS) & 10,3 & $\mathbf{1 8 , 8}$ \\
Alte tipuri histologice & 0,221 (NS) & 10,3 & 3,1 \\
\hline Grading tumoral & & & \\
G1 & $0,002^{* * *}$ & 25,9 & 0,0 \\
G2 & 0,863 (NS) & 13,8 & $\mathbf{1 2 , 5}$ \\
G3 & 0,697 (NS) & 15,5 & $\mathbf{1 2 , 5}$ \\
\hline
\end{tabular}

S-a observat că pacientele care au utilizat contraceptive orale după menopauză, pentru diverse afecţiuni, au dezvoltat cancere cu fenotipul ER+/ $\mathrm{PR}+$ în proporţie de $84,4 \%$ din totalul cazurilor studiate, faţă de fenotipul ER-/PR-, care a reprezentat doar $15,6 \%$ din totalul cazurilor studiate. Acest lucru arată că, în această situaţie, contraceptivele orale ar putea fi implicate în dezvoltarea cancerului de sân, la nivelul căruia predomină receptorii hormonali. De asemenea, s-a observat că predomină şi starea HER2 + a cancerelor de sân la aceste paciente, putându-se astfel explica şi agresivitatea mai mare a formelor de cancer şi, probabil, şi un risc de recidivă mai mare la aceste paciente. Tot în această situaţie, am observat că, la aceste paciente, ce au consumat contraceptive orale după menopauză, tu- mora de sân a avut dimensiuni cuprinse între 2 şi 7 cm în momentul descoperirii, încadrându-se în stadiul II şi IIIA de boală. A predominat carcinomul lobular, cu grading tumoral G2-G3, ceea ce poate arăta o evoluţie nefavorabilă a acestor cazuri.

Făcând o analiză a utilizării contraceptivelor orale în diversele momente din viaţa femeii, la pacientele cu cancer de sân, vom obţine următoarele rezultate statistice de importanţă deosebită.

Legat de utilizarea contraceptivelor şi fenotipul tumorii de sân, s-a observat că la pacientele care au utilizat contraceptive orale înainte de prima sarcină predomină fenotipul ER-/PR-, la cele care au folosit contraceptive orale după prima sarcină predomină fenotipul $\mathrm{ER}+/ \mathrm{PR}+$, iar la cele care au utilizat contraceptive după menopauză a predominat, de asemenea, fenotipul ER+/PR+. Altfel spus, e posibil ca dezvoltarea cancerului de sân să nu fie influenţată de contraceptivele orale dacă sunt luate înainte de prima sarcină, iar acestea ar putea influenţa dezvoltarea cancerelor de sân dacă sunt utilizate după prima sarcină şi după menopauză.

Analizând legătura dintre utilizarea contraceptivelor orale şi dimensiunea la care a fost descoperită tumora de sân, vom observa că, la pacientele care au utilizat contraceptive orale inainte de prima sarcină, dimensiunea tumorii a fost predominant $<2$ $\mathrm{cm}$, în momentul descoperirii ei; la cele care au utilizat contraceptive după prima sarcină, dimensiunea tumorii a fost cuprinsă între 2 şi $7 \mathrm{~cm}$, la fel ca în cazul pacientelor care au utilizat contraceptive după menopauză. Acest lucru ar putea sugera faptul că utilizarea cât mai precoce a contraceptivelor s-ar putea asocial cu o creştere în dimensiuni foarte mică a tumorii de sân, comparativ cu utilizarea contraceptivelor după prima sarcină şi la menopauză, când ar putea fi influenţată creşterea în dimensiuni a tumorilor de sân.

Având în vedere legătura dintre utilizarea contraceptivelor orale şi starea HER2 a tumorilor de sân, la pacientele din lotul studiat, vom observa că, dacă au fost utilizate contraceptive orale înainte de prima sarcină şi după prima sarcină, s-au dezvoltat tumori de sân cu HER2+, spre deosebire de utilizarea contraceptivelor după menopauză, când au predominat tumorile de sân cu HER2-. Alfel spus, contraceptivele orale ar putea influenţa şi agresivitatea tumorilor de sân, în funcţie de momentul din viaţa femeii, când sunt consumate.

Alt rezultat al studiului a fost legat şi de influenţa contraceptivelor orale asupra tipului histopatologic de cancer şi a gradului de diferenţiere a tumorii la pacientele din lotul studiat. S-a evidenţiat că utilizarea contraceptivelor înainte de prima sarcină a 
dus la apariţia de carcinoame ductale de sân, cu grad de diferenţiere G1, utilizarea contraceptivelor după prima sarcină a dus la apariţia de carcinoame ductale de sân cu grad de diferenţiere G2, iar utilizarea contraceptivelor după menopauză a dus la apariţia de carcinoame lobulare de sân cu grade de diferenţiere G2 şi G3. Acest lucru arată că utilizarea contraceptivelor înainte de prima sarcină s-ar putea asocia cu apariţia de cancere cu evoluţie favorabilă şi fără metastaze, în timp ce utilizarea contraceptivelor după prima sarcină şi la menopauză s-ar putea asocial cu apariţia de cancere cu evoluţie mai dificilă şi cu posibilitate crescută de a da metastaze în timp.

De asemenea, a fost luată în calcul şi legătura dintre vârsta pacientelor şi diferitele variabile ale cancerului de sân.

TABEL 8. Legătura dintre vârsta pacientelor şi fenotipul de cancer, dimensiunea tumorii de sân în momentul depistării, fenotipul asociat cu starea HER2 a tumorii, tipul histopatologic de cancer de sân şi grading-ul tumoral

\begin{tabular}{|c|c|c|c|}
\hline $\begin{array}{l}\text { Vârsta pacientelor / } \\
\text { variabile }\end{array}$ & $\begin{array}{l}\text { Nivel de } \\
\text { semnificație (p) }\end{array}$ & $\begin{array}{c}\text { Tinere } \\
(35-55 \\
\text { ani) }(\%)^{a}\end{array}$ & $\begin{array}{c}\text { Vârstnice } \\
(56-70 \text { ani } \\
(\%)^{b}\end{array}$ \\
\hline $\begin{array}{l}\text { Fenotipul tumorii } \\
\text { ER+/PR+ } \\
\text { ER-/PR- } \\
\text { ER-/PR+ } \\
\text { ER+/PR- }\end{array}$ & $\begin{array}{l}0,000^{* * *} \\
0,000^{* * *} \\
0,066^{* *} \\
0,048^{* *} \\
\end{array}$ & $\begin{array}{c}16,1 \\
77,4 \\
0,0 \\
6,5 \\
\end{array}$ & $\begin{array}{c}89,8 \\
0,0 \\
10,2 \\
0,0 \\
\end{array}$ \\
\hline $\begin{array}{l}\text { Dimensiunea } \\
\text { tumorii } \\
<2 \mathrm{~cm} \\
2-4 \mathrm{~cm} \\
>5 \mathrm{~cm}\end{array}$ & $\begin{array}{l}0,000^{* * *} \\
0,000^{* * *} \\
0,556\left(\mathrm{NS}^{\mathrm{c}}\right) \\
\end{array}$ & $\begin{array}{c}77,4 \\
16,1 \\
6,5 \\
\end{array}$ & $\begin{array}{c}0,0 \\
89,8 \\
10,2\end{array}$ \\
\hline $\begin{array}{l}\text { Fenotipul şi starea } \\
\text { HER2 a tumorii } \\
\text { ER+/PR+HER2+ } \\
\text { ER-/PR-HER2+ } \\
\text { ER+/PR+HER2- } \\
\text { ER-/PR-HER2- } \\
\text { ER+/PR-HER2- } \\
\text { ER-/PR+HER2- }\end{array}$ & \begin{tabular}{|l}
$0,012 * *$ \\
$0,000 * * *$ \\
$0,000 * * *$ \\
$0,000 * * *$ \\
$0,048 * *$ \\
$0,066^{*}$ \\
\end{tabular} & $\begin{array}{c}16,1 \\
32,3 \\
0,0 \\
45,2 \\
6,5 \\
0,0 \\
\end{array}$ & $\begin{array}{c}42,4 \\
0,0 \\
47,5 \\
0,0 \\
0,0 \\
10,2 \\
\end{array}$ \\
\hline $\begin{array}{l}\text { Tipul histopatologic } \\
\text { de cancer } \\
\text { Carcinom ductal } \\
\text { Carcinom lobular } \\
\text { Alte tipuri } \\
\text { histologice }\end{array}$ & $\begin{array}{l}0,000^{* * *} \\
0,007 * * * \\
0,046^{* *}\end{array}$ & $\begin{array}{c}48,4 \\
0,0 \\
0,0 \\
\end{array}$ & $\begin{array}{l}10,2 \\
20,3 \\
11,9 \\
\end{array}$ \\
\hline $\begin{array}{l}\text { Grading tumoral } \\
\text { G1 } \\
\text { G2 } \\
\text { G3 }\end{array}$ & $\begin{array}{l}0,000^{* * *} \\
0,007 * * * \\
0,005^{* * *}\end{array}$ & $\begin{array}{c}48,4 \\
0,0 \\
0,0 \\
\end{array}$ & $\begin{array}{c}0,0 \\
20,3 \\
22,0 \\
\end{array}$ \\
\hline
\end{tabular}

În ceea ce priveşte legătura dintre vârstă şi fenotipul cancerului de sân, la pacientele din lotul studiat, s-a constatat că pacientele tinere (35-55 ani) au preponderent fenotipul de cancer ER-/PR-, iar pacientele vârstnice (56-70 ani) au preponderent fenotipul de cancer $\mathrm{ER}+/ \mathrm{PR}+$. Acest lucru arată că pacientele tinere dezvoltă forme de cancer de sân cu responsivitate slabă la tratamentul hormonal, spre deosebire de pacientele vârstnice, care dezvoltă forme de cancer cu responsivitate crescută la tratamentele hormonale.

Legat de starea HER2 a celulelor tumorale, se observă că atât în cazul pacientelor tinere, cât şi în cazul pacientelor vârstnice, repartiţia stării HER2+/- este relativ egală pentru cele două categorii de vârstă studiate, arătând astfel că vârsta nu are o influenţă deosebită asupra stării HER2 a celulelor tumorale, la pacientele din lotul studiat.

Dacă facem o analiză între vârsta de apariţie a cancerului de sân şi dimensiunea tumorii, în momentul depistării acestuia, la pacientele din lotul studiat, vom observa că pacientele tinere au tumori cu dimensiuni de până la $2 \mathrm{~cm}$, în schimb, pacientele vârstnice au tumori cu dimensiuni cuprinse între 2 şi $4 \mathrm{~cm}$. Alfel spus, vârsta influenţează dimensiunea tumorii - şi anume, dacă tumora de sân apare la vârstă mai tânără, există posibilitatea mare ca dimensiunea tumorii în momentul descoperirii să fie mică (până în $2 \mathrm{~cm}$ ).

În ceea ce priveşte grading-ul tumoral în cancerul de sân, vârsta are, de asemenea, influenţă deosebită, astfel că la pacientele tinere predomină grading-ul tumoral G1, iar la cele vârstnice, în proporţii egale, avem grading tumoral G2 şi G3. Acest lucru arată că la pacientele tinere apar forme de cancer de sân cu evoluţie favorabilă şi fără metastaze, în timp ce la pacientele vârstnice apar forme de cancer de sân cu evoluţie mai dificilă şi cu posibilitate crescută de a da metastaze în timp.

\section{DISCUȚII}

Este ştiut faptul că, în general, cancerele care sunt considerate hormonodependente au o caracteristică aparte, şi anume aceea că, pentru dezvoltarea lor, este necesară prezenţa hormonilor $(18,19)$.

Studiile au arătat că trei sferturi dintre cancerele de sân au fost diagnosticate după menopauză. Astfel, mai puţin de 5\% dintre cazuri (1 din 20) sunt diagnosticate la tinere (sub 35 de ani). Statistic, s-a observat că riscul de a face cancer de sân este de aproximativ 1:20.000 la vârsta de 25 de ani şi creşte până la vârsta de 80 de ani, când ajunge la 1:8 $(20,21)$.

Majoritatea studiilor au arătat o creştere uşoară a riscului de cancer de sân, în cazul utilizării contraceptivelor orale. S-a observat că acest risc se diminuează după 10 ani de la oprirea terapiei. De asemenea, în zilele noastre, se utilizează contraceptive cu cantităţi mai mici de estrogen şi progesteron, iar 
ele sunt administrate mai frecvent femeilor tinere cu risc mai mic de a face cancer, conform ultimelor studii efectuate $(22,23)$.

Terapia de substituţie hormonală, adică administrarea de contraceptive postmenopauză, are unele efecte benefice, ameliorând simptomele asociate menopauzei şi având efecte benefice asupra osteoporozei. Unele studii însă, cum au fost "Women's Health Initiative", efectuat în SUA, şi "Million Women Study", efectuat în Marea Britanie, au arătat un risc crescut de a dezvolta cancer de sân la aceste femei. În prezent, nu se mai utilizează atât de frecvent această terapie, dar, atunci când este necesară, trebuie cântărite cu atenţie riscurile şi beneficiile $(24,25)$.

\section{CONCLUZII}

Contraceptivele orale nu influenţează dezvoltarea cancerului de sân dacă sunt luate înainte de prima sarcină, iar acestea ar putea influenţa dezvoltarea cancerelor de sân dacă sunt utilizate după prima sarcină şi după menopauză.

Utilizarea cât mai precoce a contraceptivelor duce la o menținere a tumorii de sân la dimensiuni mici, comparativ cu utilizarea contraceptivelor după prima sarcină şi la menopauză, care ar putea duce la o creştere a dimensiunilor tumorilor de sân până în momentul descoperirii lor.

Contraceptivele orale influenţează şi agresivitatea tumorilor de sân, în funcţie de momentul din viaţa femeii când sunt utilizate.

Utilizarea contraceptivelor înainte de prima sarcină poate duce la apariţia de cancere cu evoluţie favorabilă şi fără metastaze, în timp ce utilizarea contraceptivelor după prima sarcină şi la menopauză ar putea influenţa apariţia de cancere cu evoluţie mai dificilă şi cu posibilitate crescută de a da metastaze în timp.

Pacientele tinere dezvoltă forme de cancer de sân cu responsivitate slabă la tratamentul hormonal, spre deosebire de pacientele vârstnice, care dezvoltă forme de cancer cu responsivitate crescută la tratamentele hormonale.

Vârsta influenţează dimensiunea tumorii, şi anume: dacă tumora de sân apare la vârstă mai tânără, există posibilitatea mare ca dimensiunea tumorii în momentul descoperirii să fie mică (până în $2 \mathrm{~cm})$.

La pacientele tinere, apar forme de cancer de sân cu evoluţie favorabilă şi fără metastaze, în timp ce la pacientele vârstnice apar forme de cancer de sân cu evoluţie mai dificilă şi cu posibilitate crescută de a da metastaze în timp.

Conflict of interest: none declared Financial support: none declared

\section{BIBLIOGRAFIE}

1. IARC - International Agency for Research on Cancer: https://www. iarc.fr/featured-news/breast-cancerawareness-month-2018/.

2. Health at a Glance: Europe 2018. State of health in the UE cycle. OECD European Comission 2018, pp. 160-161).

3. Cucu MA, Cristea $C$ et al. Raportul Naţional al Stării de Sănătate al Populaţiei 2017, pp. 112-116.

4. Lafranconi A, Pylkkänen L, Deandrea S, Bramesfeld A, Lerda D, Neamţiu L, Saz-Parkinson Z, Posso M, Rigau D, Sola I, Alonso-Coello $P$, Martinez-Zapata MJ. Intensive follow-up for women with breast cancer: review of clinical, economic and patient's preference domains through evidence to decision framework. Health Qual Life Outcomes. 2017;15(1):206.

5. American Cancer Society. Cancer Facts and Figures 2012 - https:// www.cancer.org/research/cancer-facts-statistics/all-cancer-facts-figures/cancer-facts-figures-2012.html

6. Stopeck TA, Thompson PA, Chalasani P, Harris JE. Breast Cancer http://emedicine.medscape.com.

7. Peccatori FA, Azim HA Jr, Orecchia R et al. Cancer, pregnancy and fertility: ESMO Clinical Practice Guidelines for diagnosis, treatment and follow-up. Ann Oncol. 2013;24 Suppl 6:vi160-vi170.

8. Ciftlik AT, Lehr HA, Gijs MA. Microfluidic processor allows rapid HER2 immunohistochemistry of breast carcinomas and significantly reduces ambiguous (2+) read-outs. Proc Natl Acad Sci USA. 2013;110(14):5363-5368.

9. Dawood S, Broglio K, Gong Y, et al. Prognostic significance of HER-2 status in women with inflammatory breast cancer. Cancer. 2008;112(9):1905-1911.
10. Trussell J, Hatcher R, Nelson A, Cates W, Kowal D, Policar M. Contraceptive efficacy. Contraceptive technology: 20th revised edition. Ardent Media, 2011.

11. Dupouy DG, Ciftlik AT, Fiche $M$ et al. Continuous quantification of HER2 expression by microfluidic precision immunofluorescence estimates HER2 gene amplification in breast cancer. Sci Rep. 2016;6:20277.

12. El-Ibiary SY, Hardman JL. Contraception. In Alldredge BK, Corelli RL, Ernst ME, Guglielmo JJ. Koda-Kimble and Young's Applied Therapeutics The Clinical Use of Drugs. Tenth Edition. Wolters Kluver Health, Lippincott Williams\&Wilkins, 2013, pp. 1066-1090.

13. Foged NT, Anja Brügmann A, Jørgensen JT. The HER2 CISH pharmDx $\left({ }^{\mathrm{TM}}\right)$ Kit in the Assessment of Breast Cancer Patients for anti-HER2 Treatment. Expert Rev Mol Diagn. 2013;13(3):233-42.

14. Gheorghiu ARA, Mironescu A, Cobelschi C, Maier A, Toared I, Misarca C, Hogea M. Profilul hormonal de risc la pacientele cu cancer mamar. Jurnalul Medical Braşovean 2019;1.

15. Hammond MEH, Hayes DF, Dowsett M, Allred C, Hagerty KL, Badve $S$ et al. American Society of Clinical Oncology/College of American Pathologists Guideline Recommendations for Immunohistochemical Testing of Estrogen and Progesterone Receptors in Breast Cancer. Arch Pathol Lab Med 2010;134:907-22.

16. Jemal A, Siegel R, Ward E et al. Cancer statistics, 2008. CA Cancer J Clin. 2008;58(2):71-96

17. Kao KJ, Tai CH, Chang WH, Yeh TS, Chen TC, Lee GB. A fluorescence in situ hybridization (FISH) microfluidic platform for detection of HER2 amplification in cancer cells. Biosens Bioelectron. 2015;69:272-279. 
18. Sibtain A, Morgan A, MacDougall N. Physics for Clinical Oncology. Oxford University Press, Oxford, United Kingdom. 2012: pp. 325-335.

19. Templeton AJ, Gonzalez LD, Vera-Badillo FE et al. Interaction between Hormonal Receptor Status, Age and Survival in Patients with BRCA1/2 Germline Mutations: A Systematic Review and MetaRegression. PLoS One. 2016;11(5):e0154789.

20. Bevers TB, Helvie M, Bonaccio E et al. Breast Cancer Screening and Diagnosis, Version 3.2018, NCCN Clinical Practice Guidelines in Oncology. J Natl Compr Canc Netw. 2018;16(11):1362-1389.

21. Tănăsescu $C$, Coca R, Bratu D. Cancerul de sân. Editura Universitară „Carol Davila“, Bucureşti, pp. 40-50.

22. Cardoso F, Kyriakides S, Ohno S et al. Early breast cancer: ESMO Clinical Practice Guidelines for diagnosis, treatment and follow-up [published correction]. Ann Oncol. 2019;30(10):1674.
23. Senkus E, Kyriakides S, Ohno S et al. Primary breast cancer: ESMO Clinical Practice Guidelines for diagnosis, treatment and follow-up. Ann Oncol. 2015;26(Suppl 5):v8-v30.

24. Green J, Reeves GK, Floud S, Barnes I et al. Cohort Profile: the Million Women Study. International Journal of Epidemiology 2019;48(1):28-29.

25. Rossouw JE, Anderson GL, Prentice RL et al. Risks and benefits of estrogen plus progestin in healthy postmenopausal women: Principal results From the Women's Health Initiative randomized controlled trial. JAMA. 2002;288(3):321-333. 